\title{
The Effect of Transformational Leadership of Principal and School Committee on Teacher Performance in SDN Pedamaran District, Ogan Komering Ilir Regency
}

\author{
Bahren $^{1 *}$, Bukman Lian ${ }^{2}$, Syaiful Eddy ${ }^{2}$ \\ ${ }^{I}$ SD Negeri 1 Kecamatan Pedamaran, South of Sumatera, Indonesia \\ ${ }^{2}$ Universitas PGRI, Palembang, Indonesia \\ *Corresponding author. Email: bahren.bro@gmail.com
}

\begin{abstract}
This study aims to examine and analyze the effect of transformational leadership of principals and school committees on teacher performance in SDN Pedamaran District, Ogan Komering Ilir District. This study used a quantitative, descriptive method with a correlation design. The study population was 93 people, namely teachers in SD Negeri Pedamaran District, Ogan Komering Ilir Regency. The sampling technique in this study is nonprobability sampling (saturated sampling). The data collection technique used a questionnaire. Data were analyzed using correlation and multiple regression techniques. The results showed: 1) the principal's transformational leadership has a positive and significant effect on teacher performance; 2) the school committee has a positive and significant effect on teacher performance; 3) The transformational leadership of the principal and the school committee together has a positive and significant effect on teacher performance in SD Negeri Pedamaran District, Ogan Komering Ilir Regency.
\end{abstract}

Keywords: Transformational Leadership of Principal, School Committee, Teacher Performance

\section{INTRODUCTION}

Education is an essential element of a person's life and is a strategic aspect of a country. The nature of education is complex, dynamic, and contextual. Therefore, education is not an easy or straightforward thing to discuss. This education complexity illustrates that education is a serious effort because education involves cognitive, affective, and skills that will shape a person into a whole human.

Education is fundamental to improve the quality of life and determinants for social and economic development towards better conditions and is seen as the most strategic means to uplift a nation's dignity. Education must include various components and relate to one another. If education is to be carried out in a planned and orderly manner, the various elements involved must be identified first, so it is necessary to study the education business as a system. In simple terms, it can be said that the system is a whole formed from elements/parts that have functional relationships in the process of transformation or changes in one's behavior to achieve the expected quality of life.
The purpose of education has two functions, namely first, to provide direction for all educational activities. Second, it is something that all educational activities want to achieve. The purpose of education is to describe the philosophy or view of human life, both individually and in groups. Educational goals must contain the three values stated by Prihatin [1], namely (Autonomy, Equity, and Survival). Autonomy, which is to provide maximum awareness, knowledge, and abilities to individuals and groups to be able to live independently and live together in a better life. Equity means that education must allow all people to participate in cultural life and economic life by providing the same primary education. Survival, meaning that education will ensure cultural inheritance from one generation to the next.

In the current era of globalization, which is marked by advances in science and technology (IPTEK), it has led to competition for the quality of human resources (HR), thus demanding that all parties in various fields continue to improve their competence, including in the field of education.

Education always faces problems because of the gap between what is expected and the educational process's result [2]. One of the Indonesian nation's educational 
problem is the low quality of education at every level and unit of education, especially elementary education (SD). The government has made various efforts through the Ministry of Education to improve the quality of national education, for example, developing national and local curricula, increasing teacher competence through training, procuring books and learning tools, procuring and improving educational facilities and infrastructure, and improving the quality of school management.

At least three factors cause the quality of education not to increase equally, namely first, education policies and administrators. Second, national education providers are carried out in a centralized bureaucratic manner. Third, the participation of school residents. Therefore, the government places great emphasis on developing quality, effective, and efficient quality education in achieving national development goals. By stipulating the policy of Law No.22 of 1999 concerning regional autonomy and Law No.25 of 1999 concerning the balance of central and regional finance and Government Regulation No.25 of 2000 concerning the division of authority between the center and the regions, it will further open up policy opportunities Indonesian education is decentralized.

The decentralization of education is expected to encourage the improvement of services in the field of education to the community, which leads to improving the quality of education management at the lowest level (at the bottom), namely schools through the implementation of School-Based Management (MBS) "School-Based Management" as a model for implementing decentralization policies. Education is an innovative concept that is studied as a new discourse in education management and should also be considered an innovative and strategic step towards improving education quality through a management approach. School-Based Management (MBS) gives schools autonomy to be independent in developing programs, ability/potential, creativity, innovation, managing and empowering school resources by involving school members/school committees.

The educational process' success is primarily determined by the educational leaders' ability, namely the school principal, school committee, and teachers. The principal is a determining factor for a school organization's success so that the principal's performance as a leader has a vital role in carrying out the principal's function. The principal's leadership is very influential in achieving educational goals and creating conditions that are harmonious and conducive to all education components in an integrated manner and increase the relevance or suitability of education quality. The principal must have the ability to motivate his subordinates (teachers) to continue to work following their abilities and as best as possible to display a positive attitude towards their work.
Principals as managers and leaders need to have excellent abilities and need to have models and components of perspective leadership styles, idealized influence, inspirational motivation, intellectual stimulation, individualized consideration, and charisma. The principal's leadership style can influence the creation and achievement of school goals to be achieved. Principals with authoritarian leadership style will respond negatively to their subordinates by showing low performance and productivity levels. It is in line with the opinion of Umami, et al [3], the principal is a determinant of success in the school-based organization on what is expected, the duties and functions are hefty, those right stakeholders are needed in the scope of education so that the goals we want together. A clear vision and mission must accompany daily tasks' implementation must be accompanied by as the first step in running an organization.

The school committee is a supporting factor in managing education and as a relationship partner with the principal who acts as a consideration (advisory agency), supporting agency, controlling agency, mediator. The school committee is an independent forum equivalent to the Board of Educators with its independent nature; the school committee has a more significant opportunity to become a forum for community aspirations in advancing the school. School committees' role and function should focus on developing the school's physical condition, developing student qualifications, and developing teacher performance.

Teachers as educators are a component in the educational process and as the spearhead in education. Teachers must have good performance and become a foundation in achieving the quality expectations of graduates of educational institutions. Teacher performance has a significant influence in determining the level of quality of education. Teacher performance is the performance or performance performed by teachers in carrying out their duties and performing actions following predetermined goals, including planning teaching and learning programs, implementing teaching and learning processes, creating and maintaining optimal classrooms, controlling conditions. An optimal learning, as well as an assessment of learning outcomes. Therefore, every effort to improve education quality needs to pay great attention to improving teachers' quality because teacher quality is a benchmark in improving education quality.

It is in line with the expressions of Damayanti, et al [4], the characteristics of a teacher who has high performance include 1) achievement-oriented; someone who has high performance will do the job optimally, 2) have self-confidence; a teacher who has a good performance must have a high level of confidence, 3 ) have good self-control, 4) competence; a teacher who has the competence as an educator will support their performance better. 
The leadership role of school principals and school committees has enormous potential in determining teacher performance and educational organizations' success. The principal and the school committee are like two sides of a coin that have meaning and value. If one side is missing, then the money will have no value. Therefore, the two sides must be interpreted as having the same value. The success aspects of educational organizations in the current era of globalization in improving the quality of education are strongly influenced by the educational organizations themselves, namely school principals and school committees (stakeholders) in encouraging teacher performance.

The principal must be able to apply the right model and leadership style in empowering teachers because the teacher becomes the implementer at the forefront of improving the quality of education and is supported by the school committee's dimension as a pillar that accommodates and bridges the policies of the school organization. It is in line with the expressions of Permadi and Arifin [5], who state that: "An organization will succeed, and the leadership can be partially determined the leadership even failure". and added that "Educational leadership is the process of mobilizing, influencing, motivating, and directing people in educational organizations/institutions, especially to achieve goals that have been formulated. From this viewpoint, it is clear that educations' success is undoubtedly supported by the school principal's leadership and the school committee's role in optimizing teachers' function and performance in education management and creating professional teachers to improve education quality.

It is in line with the opinion of Imansyah, et al [6], in an organization, success or failure in carrying out duties and administration is influenced by leadership, through leadership, and supported by adequate organizational capacity, hence implementing good governance (Good Governance). On the contrary, it will be realized that leadership weakness is one of the causes of the collapse of Indonesia's bureaucracy's performance. Meanwhile, according to Handayani, et al [7], effective leadership is a leadership style that can produce output by managing others' performance. Leaders must ensure that subordinates carry out their work based on the skills and commitments according to their duties and functions to produce the best output.

A leadership style relevant for educational organizations is a leadership style that can collaborate from of leadership styles. The leadership styles that can support leadership styles include: (transformational, democratic, visionary, authoritarian, laissez-faire, charismatic leadership styles) to achieve optimal school organizational goals.

Thus, the principal's leadership function is an essential factor influencing teachers' performance, and managerial function. One type of leadership that is applied in educational institutions and affects teacher performance is transformational leadership

It can be seen from the results of Bariroh's [8] predecessor research entitled: The Influence of the Role of School Committees and Principal Transformational Leadership on Teacher Performance at SMP Negeri 5 Bojonegoro. State the school committee's role and the principal's transformational leadership simultaneously and significantly affect the teachers' performance at SMP Negeri 5 Bojonegoro. If the school committee's role and the principal transformational leadership are getting better, the teacher's performance will increase. It can be said that transformational leadership is future leadership that is brighter and more effective in facing the era of globalization and modernization.

The problem that arises in the Principal's current leadership is that the principal's leadership function is still relatively not optimal, primarily transformational leadership. Most principals tend to handle administrative matters, monitor teacher attendance, or make reports to supervisors. The school principal has not fully collaborated with the school committee in improving teacher performance to produce quality output. The diversity in carrying out the functions as the Principal in improving the quality of education has different implications for each school's quality.

Based on this phenomenon, the researchers linked the influence of the school principal and school committee's leadership on teacher performance in SD Negeri, Pedamaran sub-district. Researchers are interested in examining how the effect of the transformational leadership of school principals and school committees on teacher performance applied in the Pedamaran District Primary Schools, Ogan Komering Ilir District, South Sumatra Province, to improve teacher performance. With the hope that it can make a positive contribution to teacher performance in improving the quality of education in SD Negeri Pedamaran District.

\section{METHODS}

This study uses a quantitative, descriptive method with a correlation design. According to Arikunto [9], the quantitative approach is used by researchers in research by measuring variable indicators to obtain an overview and conclusions of the research problem.

According to Sugiyono [10], the quantitative approach is a research method based on the philosophy of positivism, used to research specific populations or samples, data collection using research instruments, quantitative data analysis to test predetermined hypotheses. Arikunto [9] suggested that: "The descriptive method is a research method used in studying current or present problems." This study's descriptive method is suitable for use because the problems taken are centered on the actual problem and are when the research is carried out through data 
collection procedures, classifying data, then analysis and conclusions are drawn.

The population was 93 teachers from 5 public elementary schools in Pedamaran District, Ogan Komering Ilir Regency. This study is a population study because the population is below 100 respondents, namely 93 people. The study uses a nonprobability sampling technique that provides equal opportunities for each element or member of the population to be selected as samples using saturated sampling. Saturated sampling, or the term from the census, is where all populations are sampled. In this study, the entire population of 93 people was all taken as samples [10].

The instrument used in this study was a questionnaire containing a list of attached statements. According to Widoyoko [11], a questionnaire is a data collection method carried out by giving a set of questions or written statements to respondents to be given responses in following user requests. The research questionnaire used consisted of 3 (three) pieces, namely the variable instrument of the principal's transformational leadership style, the school committee's role, and teachers' performance in SD Negeri Pedamaran sub-district. The instrument was arranged according to the variables above and distributed among 93 respondents in SD Negeri Pedamaran sub-district with alternative answers using an interval scale with a -Likert scale.

\section{RESULTS AND DISCUSSION}

\section{1) Principal Transformational Leadership $\left(X_{1}\right)$}

Principal transformational leadership variables are classified through a questionnaire consisting of 35 statement items and 5 alternative answers to statements which include indicators (1) Idealized Influence (Charismatic), (2) Inspiration Motivation (inspirational), (3) Intellectual Stimulation (Intellectual Stimulation), (4) Individualized Consideration, with the highest score of 5 and the lowest score of 1 . The following is the table of the frequency distribution responses of the principal transformational leadership variable.

Table 1. The Description of Principal Transformational Leadership ( $\left.\mathrm{X}_{1}\right)$

Descriptive Statistics

\begin{tabular}{l|c|c|c|c|c}
\hline & $\mathrm{N}$ & Min & Max & Mean & Std. Deviation \\
\hline Principal Transformational Leadership & 93 & 126 & 162 & 149,96 & 11,83116 \\
\hline Valid N (listwise) & 93 & & & & \\
\hline
\end{tabular}

Table 1 above shows that the descriptive calculation of the frequency of the transformational leadership variable for the principal with a mean value of 149.9570, Std. Deviation 11.83116, and a maximum value of 162 , a minimum value of 126 . Based on the results of the analyst's calculation data, it can be categorized as very good.

\section{2) The Description of School's Committee $\left(X_{2}\right)$}

The school committee variables are classified through a questionnaire consisting of 30 statement items and 5 alternative answers to statements, which are divided into indicators (1) Advisory Agency, (2) Controlling Agency (3) Mediator (Mediator Agency). The highest score is 5 , and the lowest score is 1 . The following is the table of frequency distribution responses from the School Committee variable.

Table 2. The Description of School's Committee $\left(\mathbf{X}_{2}\right)$

Descriptive Statistics

\begin{tabular}{l|c|c|c|c|c}
\hline & $\mathrm{N}$ & Min & Max & Mean & Std. Deviation \\
\hline School's Committee & 93 & 109 & 150 & 137,8495 & 11,29058 \\
\hline Valid N (listwise) & 93 & & & & \\
\hline
\end{tabular}

Table 2 above shows that the school committee's descriptive calculation variable with a mean value of
137.8495, Std. Deviation 11.29058, and a maximum value of 150 , a minimum value of 109 . The results of 
analyst calculation data from the school committee variable statistics can be categorized as good

\section{3) The Description of Teachers' Performance (Y)}

Teacher performance variables are classified through a questionnaire consisting of 35 statement items and 5 alternative answers to statements, which include indicators (1) Quality of Work (2) Speed / Accuracy of Work (3) Initiatives at Work (4) Evaluating or Assessing Learning, (5) Communication. The highest score is 5 , and the lowest score is 1 . The following is Table 3 of the results of the frequency distribution of the teacher performance variables.

Table 3. The Description of Teachers' Performance (Y)

\section{Descriptive Statistics}

\begin{tabular}{l|c|c|c|c|c}
\hline & N & Min & Max & Mean & Std. Deviation \\
\hline Teachers' Performance & 93 & 133 & 168 & 153,2437 & 12,31264 \\
\hline Valid N (listwise) & 93 & & & & \\
\hline
\end{tabular}

Table 3 above shows the descriptive calculation of teacher performance variables' frequency with a mean value of 153.2473, Std. Deviation 12.31264, and a maximum value of 168, a minimum value of 133 . Judging from the results of analyst calculations from the statistics of teacher performance variables, it can be categorized as good quality teacher performance.

In the Requirements Test, this research analysis consists of a normality test, a homogeneity test, and a linearity test. For normality testing, it is stated that the transformational leadership variable of the principal $\left(\mathrm{X}_{1}\right)$ and the school committee $\left(\mathrm{X}_{2}\right)$ on teacher performance $(\mathrm{Y})$ has a significant value of $0.200>$ 0.005 and is declared to be normally distributed. In the homogeneity test carried out on the principal transformational leadership variable $\left(\mathrm{X}_{1}\right)$ and the school committee $\left(\mathrm{X}_{2}\right)$ on teacher performance $(\mathrm{Y})$ shows a value of $0.69>0.05$, it can be concluded that the data distribution is homogeneous. The linearity test carried out on the variable $\left(\mathrm{X}_{1}\right)$ to $(\mathrm{Y})$ obtained the value of $\mathrm{F}$ count 48.506 and $\operatorname{sig} F=0.00<0.05$, then it is stated that the variable $\left(\mathrm{X}_{1}\right)$ to $(\mathrm{Y})$ has a linearity relationship and the variable $\left(\mathrm{X}_{2}\right)$ to $(\mathrm{Y})$, the F-count value is 489.506 and $\operatorname{sig} F=0.00<0.05$, it is stated to have linearity.

After the data is declared to have met the testing requirements, the hypothesis is tested using the test and $\mathrm{f}$ test. To know partially and simultaneously on each variable to be tested.

\section{4) The First Hypothesis Testing}

Table 4. T-test analysis

\section{Coefficients $^{\mathrm{a}}$}

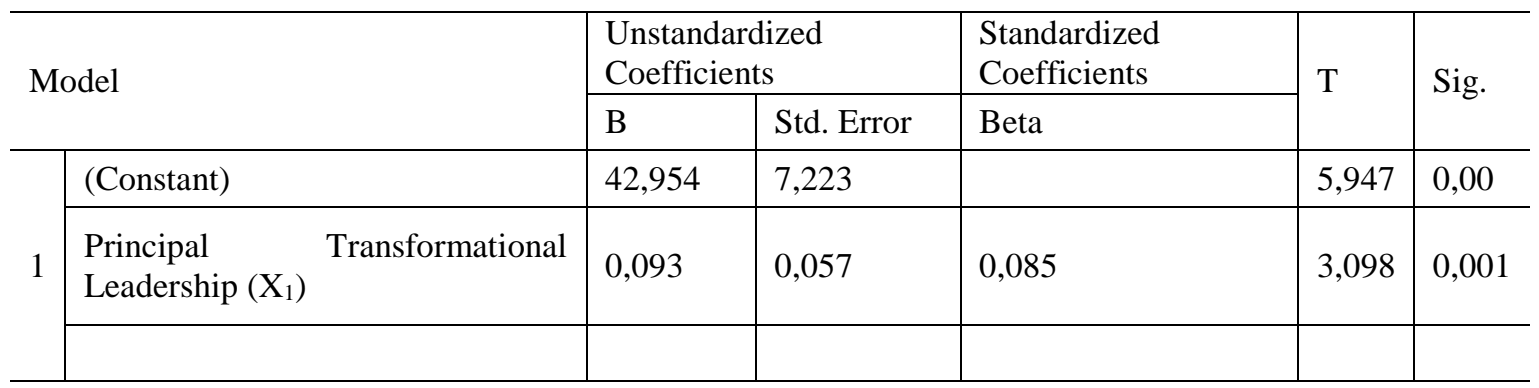

a. Dependent Variable: Teachers' Performance (Y)

Based on the calculation of the output of the t-test above, it is known that transformational leadership $\left(\mathrm{X}_{1}\right)$ on teacher performance (Y) shows a sig value of 0.01 $<0.05$ and a value of $\mathrm{t}$ count 3.098> t table 1.986. The $\mathrm{t}$ table is obtained from $\mathrm{t}$ table $=\mathrm{t}(\alpha / 2 ; \mathrm{n}-\mathrm{k}-1)$ the $\mathrm{t}$ table is 1.986 . It can be concluded that $\mathrm{H} 0$ is rejected and $\mathrm{Ha}$ is accepted, which means that there is an effect of the principal's transformational leadership on teacher performance.

\section{5) The Second Hypothesis Testing}


Table 5. The School Committee's Variable testing analysis $\left(\mathrm{X}_{2}\right)$ on Teachers' Performance (Y)

Coefficients $^{\mathbf{a}}$

\begin{tabular}{|c|c|c|c|c|c|c|}
\hline \multirow{2}{*}{\multicolumn{2}{|c|}{ Model }} & \multicolumn{2}{|c|}{ Unstandardized Coefficients } & \multirow{2}{*}{$\begin{array}{l}\text { Standardized Coefficients } \\
\text { Beta }\end{array}$} & \multirow{2}{*}{$\mathrm{T}$} & \multirow{2}{*}{ Sig. } \\
\hline & & $\mathrm{B}$ & Std. Error & & & \\
\hline & (Constant) & 42,954 & 7,223 & & 5,947 & 0,00 \\
\hline & & & & & & \\
\hline & School's Committee $\left(\mathrm{X}_{2}\right)$ & 0,739 & 0,045 & 0,862 & 16,573 & 0,00 \\
\hline
\end{tabular}

a. Dependent Variable: Teachers' Performance (Y)

Based on the data in Table 4.18, the results of the $\mathrm{t}$ test output are known for the school committee $\left(\mathrm{X}_{2}\right)$ on teacher performance $(\mathrm{Y})$, showing the sig value of 0.00 $<0.05$ and the $t$ value of $16.573>\mathrm{t}$ table 1.986 . So, it can be concluded that $\mathrm{HO}$ is rejected and $\mathrm{Ha}$ is accepted, which means it is significant so that it can be stated that there is an influence of the school committee on teacher performance.

6) The Third Hypothesis Testing

Table 6. Simultaneous testing of analysis (F) variable $X_{1}$ and $X 2$ on $Y$

ANNOVA ${ }^{\mathrm{a}}$

\begin{tabular}{c|l|r|r|r|r|l}
\hline \multicolumn{2}{l|}{ Model } & Sum of Squares & Df & Mean Square & F & Sig. \\
\hline \multirow{2}{*}{1} & Regression & 10816,596 & 2 & 5408,298 & 225,231 &, $000^{\mathrm{b}}$ \\
\cline { 2 - 7 } & Residual & 2161,103 & 90 & 24,012 & & \\
\cline { 2 - 7 } & Total & 12977,699 & 92 & & & \\
\hline
\end{tabular}

a. Dependent Variable: Teachers' Performance

b. Predictors: (Constant), School Committee, Principal Transformational Leadership

Based on Table 4.21, it is known that the sig value of $0.000<0.05$ and the value of $F$ count 225.231>3.097 $\mathrm{F}$ table. From the results of the output in table 4.20 it can be concluded that there is an effect of variable $\mathrm{X}$ simultaneously on variable $\mathrm{Y}$.

\section{CONCLUSION}

Based on the results of the analysis and research discussion regarding the effect of transformational leadership of school principals and school committees on teacher performance in SD Negeri Pedamaran District, Ogan Komering Ilir Regency, it can be concluded that there is a significant favorable influence between the transformational leadership of principals on teacher performance in SD Negeri Pedamaran District. Ogan Komering Ilir District. There is a significant positive effect between school committees on teacher performance in SD Negeri Pedamaran District, Ogan Komering Ilir Regency. There is a significant favorable influence between the principal transformational leadership and the school committee on teacher performance in SD Negeri Pedamaran District, Ogan Komering Ilir District.

\section{ACKNOWLEDGMENTS}

Our deepest gratitude goes to Teachers in SD Negeri 1 Kecamatan Pedamaran, Chancellor of Palembang PGRI University, Director of the Postgraduate Program of PGRI Palembang University and the Education Management Study Program of PGRI Palembang University, who have supported us in doing this extraordinary thing. This project is funded independently. We also want to thank our Education Management friends who helped us a lot in a short time frame to complete this project.

\section{REFERENCES}

[1] Prihatin, E. (2008). Konsep Pendidikan [Concept of Education]. Bandung: PT Karsa Mandiri Persada.

[2] Syah, M. (2010). Psikologi Pendidikan dengan Pendekatan Baru [Educational Psychology with a New Approach]. Edisi Revisi. Bandung: PT. Remaja Rosdakarya.

[3] Umami, Lian, Bukman, \& Missriani, (2021). Pengaruh Kepemimpinan dan Motivasi Kerja Guru Terhadap Disiplin Kerja [ The Effect of Leadership and Teacher Work Motivation on 
Work Discipline]. JMKSP (Jurnal Manajemen, Kepemimpinan, dan Supervisi Pendidikan).

[4] Damayani, T., Arafat, Y., \& Eddy, S. (2020). Pengaruh Kepemimpinan Kepala Sekolah dan Motivasi Kerja terhadap Kinerja [The Influence of Principal Leadership and Work Motivation on Performance]. Journal of Innovation in Teaching and Instructional Media.

[5] Permadi, D., Arifin, D. (2007). Kepemimpinan Transformasional Kepala Sekolah dan Komite Sekolah [Transformational Leadership of Principals and School Committees]. Bandung: PT Sarana Panca Karya Nusa.

[6] Imansyah, M., Arafat, Y., \& Wardiah, D. (2020). Pengaruh Kepemimpinan Kepala sekolah dan Partisipasi Komite Sekolah Terhadap Kinerja Guru [The Influence of Principal Leadership and School Committee Participation on Teacher Performance]. JMKSP (Jurnal Manajemen, Kepemimpinan, dan Supervisi Pendidikan), 5(2).

[7] Handayani, Esti., Lian, Bukman., \& Rohana, (2021). Kinerja Guru Ditinjau Dari Pengaruh Budaya Organisasi dan Gaya Kepemimpinan Kepala Sekolah [Teacher Performance Viewed From the Influence of Organizational Culture and Principal Leadership Style]. JMKSP (Jurnal Manajemen, Kepemimpinan, dan Supervisi Pendidikan).

[8] Bariroh, S. (2018). Pengaruh Peran Komite Sekolah dan Kepemimpinan Transformasional Kepala Sekolah terhadap Kinerja Guru SMP Negeri 5 Bojonegoro [The Influence of the Role of the School Committee and the Principal's Transformational Leadership on Teacher Performance at SMP Negeri 5 Bojonegoro]. Jurnal Jendela Pendidikan.

[9] Arikunto, S. (2010). Prosedur Penelitian Suatu Pendekatan Praktik [The Research Procedure Is a Practical Approach]. Jakarta: Rineka Cipta.

[10] Sugiyono. (2013). Metode Penelitian Pendidikan Pendekatan Kualitatif dan $R \& D$ [Educational Research Methods with Qualitative Approaches and $R \& D$ ]. Bandung: Alfabeta.

[11] Widoyoko, P.E.S. (2012). Teknik Peyusunan Penelitian [Research Compilation Techniques]. Yogyakarta: Pustaka Pelajar. 